\title{
HIDDEN INEQUALITY IN LOMCE
}

Verónica Arjona Castilla and María López Muñoz. Universidad de Granada

Artículo dirigido por: Katia Caballero. Departamento de Didáctica y Organización Escolar. Universidad de Granada

Fecha de recepción: 31 de enero de 2014.

Fecha de revisión: 19 de marzo de 2014.

Fecha de aceptación: 11 de abril de 2014.

\section{ABSTRACT}

The Organic Law for the Improvement of the Educational Quality (LOMCE) supposes a step back in the development of education. The huge number of critics about this reform gives us a guideline to comment and value some weaknesses of this law. Through the explanation of two main topics: gender segregation and privatization of schools, one can see the negative effect that LOMCE hides: inequality.

KEYWORDS: Educational policy; educational reform; free education; right to education; scholar segregation.

\section{RESUMEN}

La Ley Orgánica para la Mejora de la Calidad Educativa (LOMCE) supone un retroceso en el desarrollo de la educación. El inmenso número de críticas que ha recibido nos sirve de guía para comentar y valorar algunas de sus carencias. Mediante la exposición de dos de sus tópicos más populares: segregación por sexos y la privatización de la enseñanza, se muestra la gran desigualdad educativa que dicha ley promueve.

PALABRAS CLAVE: Política educativa; reforma educativa; educación gratuita; derecho a la educación; segregación escolar.

\section{INTRODUCTION}

The Organic Law 8/2013, December $9^{\text {th }}$, for the Improvement of the Educational Quality (LOMCE), or the so called "Wert Law", has been the last Spanish educational law approved by the Council of Ministers.

The Spanish Educational System has been modified by many different educational reforms from several political parties. However, and according to Bolívar (2012:1), "the successive educational reforms, which have been centered on the curriculum, have not truly changed our schools". This is the main reason for our current worrying situation.

LOMCE is supposed to be a modification of some aspects of the Organic Law of Education, 2006 (LOE). Nevertheless, its intrinsic ideology is completely different. 
This law directly reduces equal educational opportunities and the comprehensiveness of our current Educational System. Due to this, LOMCE has been, and is, a polemic and rejected law by the educational community and others.

From an international perspective, it is well known that Finnish Educational System is the main referent in global education. According to Sahlberg (2011), the reforms proposed by LOMCE go in the opposite direction of the Finnish ones.

Along this article, two relevant changes proposed by LOMCE are going to be analyzed: gender segregation and the privatization of education.

\section{SEGREGATION}

LOMCE will provide subsidies to those subsidized schools that support gender segregation: (amendment of paragraph 3 or Article 84) It will not be possible in any case to make discriminations by reasons of birth, race, sex, religion, opinion or whatever other personal or social circumstance. What has been said in the previous paragraph will not be an obstacle for sex-segregated schools to receive the referred subsides of the article 116 of this organic law, if the provided education follows the disposals of the article 2 of the Convention on the fight against discrimination in the teaching of December 14, 1960 (Organic Law for the Improvement of the Educational Quality, 2013:46-47).

The previous extract means that a school that follows the segregated educational model is totally comparable with the rest of schools, which follow the coeducational principle, although we strongly doubt about this interpretation.

\section{Segregated school versus mixed school}

Segregated schools were intended to differentiate the type of education received by girls and boys; destined to occupy different roles in society. However, with the emergence of the mixed school, it took the first step towards overcoming the problem of inequality of girls and women in the education of our country (Morata, 2012:25).

There are several reasons that justify the gender segregation: families have the right of election and the apparent increased level of performance reached by girls. Both are strategic arguments which are considered to eliminate the right of an integral and mixed education.

Furthermore, gender segregation is supported by the ultraconservative ideology of the Catholic Church, who holds the view that men and women are educated separately because they have different destinations (Morata, 2012:25-26).

Therefore, it can be considered as an attack to the Article 14 of the Spanish Constitution and a great reinforcement of gender stereotypes in our current society.

As Morata (2012) stresses, the implementation of a segregated school will suppose a setback to the democratic gains won in the previous century. 
A mixed school, through coeducation, is going to provide a positive and joint socialization. Like Martínez (2013) says, coeducation is a type of education centered on the equality of rights and opportunities for students, whose intention is to overcome androcentrism.

Moreover, schools must be a space that guaranty to citizens an education based in values, especially gender equality. This is supported by the European countries, where public education is taught in mixed schools.

Segregated stimulates different learning styles, reinforcing those aspects in which students are strong, and forgetting their weaknesses. It has also been demonstrated that it created a sexist regime in some boys (Younger \& others, 2005).

Finally, it is necessary to highlight that sex segregation does not improve academic results. It is not true that boys and girls learn differently. However, there is clear evidence that this form of organizing the schooling increases gender stereotypes and legitimizes institutional sexism (Halpern, 2011).

\section{THE PRIVATIZATION OF EDUCATION}

The current privatizing trend in Spain, as well as in other countries, defends "a focus just on the economic usefulness of education" (Postman, 1999:44). Knowledge about the relation between education and the economic development of a country is essential, but it is convenient to both adopt a philosophy centered in long-term profits instead of short-term winnings and orientate educational responsibilities to higher aims than the economic ones (Morata, 2012: 18-20).

Both historical data and market demand affirm the idea that educational economic usefulness is, simply, a sub product of an adequate educational process. Nevertheless, it seems that the people who have created the LOMCE do not have this interdisciplinary view, since they exhibit explicitly a clear subordination of economic interests to education (Morata, 2012: 18).

In this case, economy is being considered as the base of the financial character of the schools. How LOMCE has presented this topic has been one of the most controversial themes, so it is going to be explained throughout the present article.

Nowadays, there are three kinds of schools changing their economic dependence to the State: private (totally independent), public (totally dependent) or state-subsidized (dependent in some aspects) schools.

In 1985, the Organic Law of the Right to Education (LODE) was approved. It promoted the subsidization of many public schools as a way to put away public money in the creation of new schools (because they were already constructed). But since then and with other aims, public economic resources put aside for state-subsidized education has increased immensely. Consequently, it has created inequality (segregation, exclusion of immigrants...) in matters of education (Morata, 2012: 22).

LOMCE goes deeper and proposes a new definition of the Spanish Educational System (Art. 2.bis). It situates public, state-subsidized and private schools in equality of 
conditions. In practice, it means the consecration of businesses that finance or regulate the process of education, opening the door to the privatization of educational process.

Furthermore, it transforms deeply the $109^{\text {th }}$ article of the LOE, eliminating the term "public schools" as well as the obligation of the Spanish State to guarantee a public, free and high quality education (Morata, 2012: 23). In addition, they establish the possibility to create private schools with public money.

All the above-presented facts make some professionals in the field of education, as Bernal and Lorenzo (2013), conclude that the development of processes of privatization in education is going to promote a higher inequality in our society. It will look like the sixties in Spain, when only 3\% of students who entered in Primary Education managed to study at the University.

As Gómez-Llorente (2000) affirmed, "public schools could be as brilliant as private ones". However, "it is necessary to stop an irreparable damage to public education that has been achieved thanks to hard efforts during the XX century" (Juliá, 2011:24).

According to the OCDE report, currently in Spain, there is a weak presence of public education in favor of private schools (Morata, 2012:21). This situation will get worst with the LOMCE's approval because it promotes a society based on economic power and prestige, based on "capitalism values"” (Bernal \& Lorenzo, 2013).

Furthermore, LOMCE raises a curricular and functional specialization of schools. It is true that schools should have the opportunity to offer individualized educational processes attending to the characteristics of their surroundings; a certain degree of "specialization" could be beneficial. However, the process of specialization must be oriented to the adaptation of the educational system for those who really need it, instead of looking for an acceptance from the "customers" (wealthy families) (Bolívar, 2012: 12).

All changes proposed by LOMCE do not care about social values and the right to education, so they will only benefit the high social classes.

\section{CONCLUSIONS}

LOMCE proposes many different changes. However, it does not address the most important core of education: how teachers teach and how students learn (Bolívar, 2012: 2).

As Bolívar stresses, LOMCE defends an ancient and old pedagogy. It will promote a huge relapse of our current educational model.

Gender segregation created by LOMCE is a clear example against equity. Moreover, it does not enhance academic results but damages the principles of coeducation directed, according to Cabeza (2010), "to correct sexist stereotypes, to propose an equilibrated curriculum which eliminates slant and to develop all the individual capacities independently of gender."

In relation to the privatization of the education, LOMCE shows its agreement with it. Politicians from the most important Spanish right wing party, that have created the present law, have eliminated the term "public school", avoiding its use throughout the 
law. This fact promotes, both intrinsically and extrinsically, a subordination of public education to private one, which could be translated in a huge decrease of the equity, comprehensiveness and accessibility of our current educational system, which since now, has been the second more egalitarian educational system in Europe.

Finally, and in relation to all the objective data presented, we strongly believe that a continuous change of educational laws is harmful to the whole educational system instead of improving it. For that reason, and some others, we consider that the best solution would be to reach a consensus between all political parties and to create a law that gives advantage to everybody. Members of the educational field must elaborate it because they are the unique ones that really know what education is about.

\section{REFERENCES}

Bernal, J.L. \& Lorenzo, J. (2013). La privatización de la Educación Pública. Una tendencia en España, un camino encubierto hacia la desigualdad. Profesorado: Revista de Currículum y Formación del Profesorado, 16.

Bolívar, A. (2012). Hastiados de reformas educativas. Revista Escuela, 3956, 37.

Bolívar, A. (2013). Volver a políticas educativas fracasadas. Revista Escuela, 3972, 37.

Bolívar, A. \& San Fabián, J. (2013). La LOMCE, ¿una nueva ley para mejorar la calidad educativa? Organización y Gestión Educativa, 1, 7-11.

Caballero, K. (2013). Unit 2, Spanish Educational System background, 8.

Cabeza, J. (2010). Importancia de la coeducación en los centros educativos. Pedagogía Magna, 8, 40-45.

Constitución Española, de 27 de diciembre de 1978. Boletín Oficial del Estado, 29 de diciembre de 1978.

Fórum de Aragón (2013). La LOMCE, la reforma que viene. Revista digital del Fórum Europeo de Administradores de la Educación de Aragón, 7.

Ley Orgánica 8/2013, de 9 de diciembre, para la Mejora de la Calidad Educativa (BOE, $\mathrm{N}^{\circ} 295$ 10-12-2013).

Morata, J. (2013). Por otra política educativa. Madrid: Ediciones Morata.

Soy Pública collective. (2013). Anteproyecto de la LOMCE analizado. Retrieved from http://soypublica.wordpress.com/2012/10/08/lo-que-esconde-la-lomce-analisisdel-anteproyecto-de-ley-de-educacion/. 